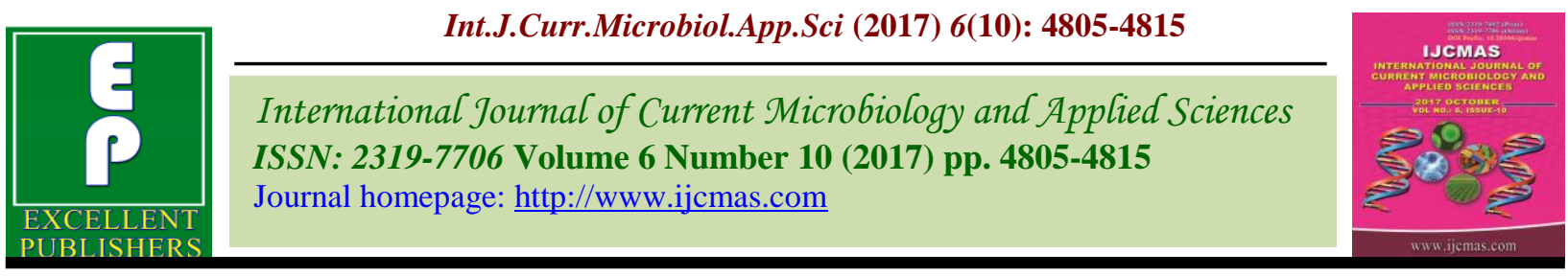

Original Research Article

https://doi.org/10.20546/ijcmas.2017.610.448

\title{
Decadal Trend Analysis of Annual and Seasonal Rainfall of Past 115 Years at South Gujarat, India
}

\author{
Neeraj Kumar, S.K. Chandrawanshi*, N.V. Chaudhari, Ashok Patidar, \\ S.N. Chaudhari and G.G. Radadia \\ Agricultural Meteorological Cell, Department of Agricultural Engineering, N. M. College of \\ Agriculture, Navsari Agricultural University, Navsari- 396 450, Gujarat, India \\ *Corresponding author
}

\begin{tabular}{|c|c|}
\hline & A B S T R A C T \\
\hline Keywords & $\begin{array}{l}\text { The aim of the present study is to analysis rainfall time series, detecting } \\
\text { potential trends and assessing their significance. The present study shows }\end{array}$ \\
\hline $\begin{array}{l}\text { Excess and deficit } \\
\text { rainfall, Decadal } \\
\text { trend. }\end{array}$ & $\begin{array}{l}\text { the increase in southwest monsoon rainfall and decline in post monsoon } \\
\text { rainfall for all the districts of south Gujarat. Similarly annual rainfall }\end{array}$ \\
\hline Article Info & Surat acknowledges increasing rainfall pattern on most of decades. The \\
\hline $\begin{array}{l}\text { Accepted: } \\
\text { 29 September } 2017 \\
\text { Available Online: } \\
10 \text { October } 2017\end{array}$ & $\begin{array}{l}\text { more number of excess rainfall years were found in Dang, Valsad and Surat } \\
\text { as compared to Navsari and Bharuch districts. Similarly the more number } \\
\text { of deficit rainfall years were found in Navsari and Bharuch as evaluated to } \\
\text { Dang, Valsad and Surat districts. }\end{array}$ \\
\hline
\end{tabular}

\section{Introduction}

In India, rainfall variability is a central driver of the national economy. Although a considerable volume of Himalayan water flows into India, in situ rainfall is the main resource for agriculture which generates about $20 \%$ of the national GDP (CIA, 2012). More than half of the country's population depends on agriculture for their livelihoods. Dry years negatively impact grain production, food security and GDP (Gadgil and Gadgil, 2006). Indian climate is dominated by the southwest Monsoon accumulating $70 \%-90 \%$ of annual precipitation between June and September. The monsoon onset occurs during the boreal spring in response to contrasted warming rates between South and Southeast Asian land regions and the surrounding oceans. Warmer land areas generate a large-scale meridional surface temperature gradient and the establishment of a low pressure region, inducing a northward excursion of the intertropical convergence zone (ITCZ), and bringing moisture from the Arabian Sea and the Bay of Bengal toward India. The Himalayan range reinforces this phenomenon by ensuring air heats up to the troposphere. Furthermore, the East African highlands guide the south-north cross equatorial flows aided by the Earth's rotation to form the lowlevel westerly jet as it approaches South Asia 
(Turner and Annamalai, 2012). During the post-monsoon (October-December), the land mass cools, the ITCZ retreats south bringing dry, cool, and dense Central Asian air masses to India. This marks the transition from wet to dry conditions in most parts of India. However, due to the rain shadow effect and to the north-easterlies collecting moisture over the Bay of Bengal, the extreme southeast peninsula receives reliable rainfall only during the post-monsoon (Ranade et al., 2008). In winter (January-February), most of the country is dry except the extreme southern Peninsula and Northeast India which receive light rainfall. The initiation of the contrasted land-sea warming determines the monsoon onset during the pre-monsoon (March-May) and is marked by a high inter-annual rainfall variability (Ranade et al., 2008). Inter-annual monsoon rainfall variations are predominantly controlled by the tropical pacific sea surface temperature (SST) anomalies related to $\mathrm{El}$ Nino Southern Oscillation (ENSO) (Kumar et al., 2006). Anthropogenic climatic changes are believed to be influencing long-term monsoon patterns (Turner and Annamalai, 2012) and will likely impact the country's food security and economic development. Against this background, insights into historical rainfall trends are necessary for both agricultural and water development planning.

Rainfall in the humid tropics varies from place to place in the short-term (days) and this gives much variation at the local scale, depending on the movement and size of storm cells. Convective precipitation is an important component of the tropical weather system and contributes to the spatial and seasonal variability of rainfall. The dynamic properties of convective precipitation affect runoff response, while the spatial variability of rainfall is important in determining the volume and timing of rain transformed into runoff Currently, predicting the spatial and temporal distribution of rainfall also important due to climate change.

However, very little work has been done on Gujarat state. Ray et al., (2009) studies climate variability and extreme weather events like cold wave and heat wave condition and heavy rainfall events in Gujarat and they recorded a significant steady increase in these events. Lunagaria et al., (2015) examined the rainfall patterns of Gujarat state, rainfall indices also showed no uniformity for any negative or positive trend over Gujarat. Total annual rainfall and extremely wet days were found to increase at more numbers of stations. As the rainfall is the parameter having very high variability, very few stations showed statistically significant trends. Thus, still there is ambiguity in the rainfall pattern for Gujarat state. The Indian Meteorological department views Gujarat state as two Sub-divisions, Gujarat region and Saurashtra- Kutch region. The state's annual average rainfall is about $820 \mathrm{~mm}$ received in 30 rainy days. The annual average rainfall Gujarat region $970 \mathrm{~mm}$ received in 43 rainy days, while that of Saurashtra- Kutch region is only $580 \mathrm{~mm}$ received in an average in only 23 rainy days. The coefficient of variation ( $\mathrm{CV} \%$ ) of rainfall for Gujarat region is $23 \%$ and that of Saurashtra-Kutch is 35 percent. Considering Bharuch-Deesa line, the rainfall in the state decreases towards west of the line (Sahu, 2007).

\section{Materials and Methods}

In south Gujarat five locations were selected for assessment of scare and excess rainfall intensity and frequency (1) Navsari $\left(23.15^{\circ} \mathrm{N}\right.$ and $69.49^{\circ} \mathrm{E}$, Altitude $11.0 \mathrm{~m}$ ) (2) Bharuch $\left(22.98^{\circ} \mathrm{N}\right.$ and $70.21^{\circ} \mathrm{E}$, Altitude $\left.3.0 \mathrm{~m}\right)(3)$ Surat $\left(22.98^{\circ} \mathrm{E}\right.$ and $70.21^{\circ} \mathrm{E}$, Altitude $\left.3.0 \mathrm{~m}\right)$ (4) Valsad $\left(22.35^{\circ} \mathrm{N}\right.$ and $72.35^{\circ} \mathrm{E}$, Altitude $6.10 \mathrm{~m})$ and (5) Dang $\left(20.51^{\circ} \mathrm{N}\right.$ and $70.21^{\circ} \mathrm{E}$, 
Altitude $440 \mathrm{~m}$ ) (fig.1-2). The historical monthly and annual rainfall data were used of 115 years (1901-2015). By using monthly rainfall data, monthly mean, seasonal averages, were computed monthly and season-wise viz., South-west monsoon (JuneSeptember), Post-monsoon (OctoberNovember) and Annual (January-December). The data were subjected to find out long term trends. A linear rend line was added to the series for simplify the trends. To support the trends in annual, seasonal rainfall and decadewise shifts in rainfall were also analyzed.

\section{Linear regression analysis}

Linear regression analysis is a parametric model and one of the most commonly used methods to detect a trend in a data series. This model develops a relationship between two variables (dependent and independent) by fitting a linear equation to the observed data. The data is first checked whether or not there is a relationship between the variables of interest. This can be done by using the scatter plot. If there appears no association between the two variables, linear regression model will not prove a useful model.

A numerical measure of this association between the variables is the correlation coefficient, which range between -1 to +1 . A correlation coefficient value of \pm 1 indicates a perfect fit. A value near zero means that there is a random, nonlinear relationship between the two variables. The linear regression model is generally described by the following equation:

$Y=m \cdot X+C(3)$

Where, $Y$ is the dependent variable, $X$ is the independent variable, $m$ is the slope of the line and $C$ is the intercept constant. The coefficients ( $m$ and $C$ ) of the modal are determined using the Least-Squares method, which the most commonly used method. t-test is used to determine whether the linear trends are significantly different from zero at the $5 \%$ significance level.

\section{Results and Discussion}

\section{Shift in decade-wise annual and seasonal rainfall}

The deficient are excess rainfall years are defined for those years when rainfall is less or more than the normal. Pant and Rupa Kumar (1997) reported that Indian summer monsoon displays multi-decadal variations in which there is clustering of dry or wet anomalies. The decadal trend analysis of annual and seasonal rainfall for Dang, Valsad, Surat, Navsari and Bharuch and frequencies of excess and deficient years during monsoon, post monsoon and annual period are depicted in tables 1-3.

\section{Navsari district}

\section{Annual}

The analysis of annual rainfall reveals that at Navsari district the 43 excess and 72 deficit years were observed. During decades 194150, 1951-60 and 1961-70 highest rainfall were recorded with percent increase 26.64, 26.37 and 19.83 respectively. Similarly, during decades 1981-90, 1991-2000 and 2001-15 lowest rainfall were recorded with percent decrease $\quad-47.53, \quad-46.10$ and -13.81 respectively.

The examination of annual rainfall affirms that at Navsari district, during decades 194150, 1951-60 and 1961-70 excess incidents of rainfall were noticed with no. 7, 6 and 4 respectively. Likewise, in the mean while decades 1981-90, 1991-2000 and 2001-15 deficit rainfall events were inscribed with no. 10, 9 and 13 respectively (Table 1 ). 


\section{Monsoon}

The investigation of monsoon rainfall explains that at Navsari district, the 55 excess and 60 deficit years were observed. All along decades 1941-50, 1951-60 and 1961-70 highest rainfall were registered along with percent increase $16.84,14.47$ and 12.35 respectively.

Correspondingly, meanwhile decades 198190, 1991-2000 and 1921-30 nethermost rainfall were recorded with percent decrease $33.11,-16.55$ and -6.91 respectively (Table $1)$.

The study of monsoon rainfall concedes that at Navsari district, during decade 2001-15, 1941-50 and 1971-80 highest excess events of rainfall were perceived with no. 9,7 and 6 respectively.

Similarly, all the while decades 1981-90, 1991-2000 and 2001-15 deficit rainfall cases were reported with no. 9, 8 and 6 respectively.

\section{Post monsoon}

The analysis of post monsoon rainfall imparts that at Navsari district, the 36 excess and 79 deficit years were observed. During decades 1911-20, 1931-40 and 1951-60 highest rainfall were recorded with percent increase 92.74, 92.92 and 49.23 respectively. Furthermore, amid decades 1961-70, 1901-10 and 2001-15 lowest rainfall were recorded alongside percent decrease $-64.72,-58.43$ and -53.56 respectively (Table 1 ).

The appraisal of post monsoon rainfall make known that at Navsari district, as decades 1911-20, 1931-40 and 1941-50 highest excess incidents of rainfall were discerned with no. 5,5 and 4 respectively. Then as well, during decades 2001-15, 1901-10 and 1921-30 deficit rainfall events were documented with no. 12,9 and 8 respectively.

\section{Bharuch district}

\section{Annual}

The analysis of annual rainfall acknowledges that at Bharuch district, the 45 excess and 70 deficit years were detected. In decades 194150, 1951-60 and 1961-70 highest rainfall were recorded amidst percent increase 17.64, 14.19 and 2.49 respectively.

Correspondingly, during decades 1991-2000, 2001-15 and 1981-90 lowest rainfall were recorded with percent decrease $-50.31,-36.05$ and -11.65 respectively.

The assessment of annual rainfall reveals that at Bharuch district, at the time decades 193140, 1941-50 and 1951-60 excess incidents of rainfall were observed with no. 6,6 and 6 respectively. Similarly, during decades 200115, 1991-2000 and 1981-90 deficit rainfall cases were registered with no.13, 10 and 7 respectively (Table 1).

\section{Monsoon}

The analysis of monsoon rainfall divulges that at Bharuch district, the 61 excess and 54 deficit years were observed. In the course of decades 1941-50, 1951-60 and 1961-70 highest rainfall were observed with percent increase 17.15, 12.44 and 1.01 respectively. Alike, during decades 1991-2000, 1901-10 and 1911-20 lowest rainfall were recorded with percent decrease $-9.50,-7.83$ and -5.44 respectively.

The study of monsoon rainfall concedes that at Bharuch district, in the interim of decades 2001-15, 1941-50 and 1951-60 highest excess events of rainfall were noticed with no. 8,8 and 6 respectively. Correspondingly, during decades 2001-15, 1981-90 and 1991-2000 deficit rainfall cases were documented with no. 7, 6 and 6 respectively (Table 1). 


\section{Post monsoon}

The analysis of post monsoon rainfall divulges that at Bharuch district, the 35 excess and 80 deficit years were observed. In the mean while decades 1911-20, 1931-40 and 1951-60 highest rainfall were recorded including percent increase $101.19,89.90$ and 69.77 respectively.

Furthermore, during decades 1901-10, 196170 and 1991-2000 lowest rainfall were recorded with percent decrease $-81.81,-61.40$ and -25.77 respectively (Table 1 ).

The study of pre monsoon rainfall explains that at Bharuch district, meanwhile decades 1931-40, 1911-20 and 1951-60 highest excess incidents of rainfall were observed with no. 6 , 4 and 4 respectively. Thus, during decades 2001-15, 1901-10 and 1961-70 deficit rainfall events were listed with no. 13, 9 and 9 respectively.

\section{Surat district}

\section{Annual}

The analysis of annual rainfall acknowledges that at Surat district, the 51 excess and 64 deficit years were noticed. During decades 2001-15, 1971-80 and 1951-60 highest rainfall were recorded along with percent increase $14.95,6.50$ and 6.38 respectively. Similarly, during decades 1901-10, 1911-20 and 1921-30 lowest rainfall were remarked with percent decrease $-18.44,-10.46$ and 6.66 respectively.

The study of annual rainfall admits that at Surat district, thought decades 2001-15, 196170 and 1971-80 excess events of rainfall were observed with no. 8,5 and 5 respectively. In addition, while decades 1901-10, 1981-90 and 2001-15 deficit rainfall cases were perceived with no. 7, 7 and 7 respectively (Table 2).

\section{Monsoon}

The analysis of monsoon rainfall reveals that at Surat district, the 50 excess and 65 deficit years were observed. During decades 200115, 1971-80 and 1961-70 highest rainfall were recorded alongside percent increase 17.53, 6.79 and 5.80 respectively.

Similarly, all along decades 1901-10, 1911-20 and 1921-30 lowest rainfall were recorded with percent decrease $-17.28,-14.19$ and 5.85 respectively.

The study of monsoon rainfall declares that at Surat district, all the while decades 2001-15, 1961-70 and 1971-80 highest excess incidents of rainfall were chronicled with no. 10, 5 and 5 respectively. A like, in the course of decades 1901-10, 1911-20 and 1981-90 deficit rainfall cases were documented with no. 7, 7 and 7 respectively (Table 2 ).

\section{Post monsoon}

The study of post monsoon rainfall reveals that at Surat district, the 36 excess and 79 deficit years were registered. During decades 1921-30, 1911-20 and 1951-60 highest rainfall were observed amidst percent increase $95.52,86.76$ and 61.50 respectively.

Correspondingly, in the interim of decades 1901-10, 1961-70 and 2001-15 lowest rainfall were listed with percent decrease -71.90, 69.53 and -45.71 respectively.

The analysis of post monsoon rainfall divulges that at Surat district, in the mean while decade 1931-40, 1911-20 and 1971-80 highest excess incidents of rainfall were observed with no. 6, 5 and 5 respectively. Similarly, during decades 2001-15, 1901-10 and 1921-30 deficit rainfall cases were cataloged with no. 13, 10 and 9 respectively (Table 2). 


\section{Int.J.Curr.Microbiol.App.Sci (2017) 6(10): 4805-4815}

Table.1 Decadal mean (\% departure from normal) of excess, deficit rainfall and linear equation and over Navsari and Bharuch from 1901 to 2015

\begin{tabular}{|c|c|c|c|c|c|c|c|c|c|}
\hline \multirow[b]{2}{*}{ Decades } & \multicolumn{2}{|l|}{ Monsoon } & \multicolumn{3}{|c|}{ Post-monsoon } & \multicolumn{4}{|c|}{ Annual } \\
\hline & $\begin{array}{c}\text { Decadal mean } \\
\text { (\% departure from normal) }\end{array}$ & Excess & Deficit & $\begin{array}{c}\text { Decadal mean } \\
\text { (\% departure from } \\
\text { normal) }\end{array}$ & Excess & Deficit & $\begin{array}{c}\text { Decadal mean } \\
\text { (\% departure from } \\
\text { normal) }\end{array}$ & Excess & Deficit \\
\hline \multicolumn{10}{|c|}{ Navsari } \\
\hline $1901-10$ & -1.99 & 5 & 5 & -58.43 & 1 & 9 & 5.31 & 4 & 6 \\
\hline $1911-20$ & 0.55 & 5 & 5 & 92.74 & 5 & 5 & 14.22 & 5 & 5 \\
\hline $1921-30$ & -6.91 & 4 & 6 & -48.80 & 2 & 8 & 0.45 & 3 & 7 \\
\hline $1931-40$ & -3.53 & 5 & 5 & 92.92 & 5 & 5 & 8.43 & 5 & 5 \\
\hline $1941-50$ & 16.84 & 7 & 3 & -18.65 & 4 & 6 & 26.64 & 7 & 3 \\
\hline $1951-60$ & 14.47 & 6 & 4 & 49.23 & 3 & 7 & 26.37 & 6 & 4 \\
\hline $1961-70$ & 12.35 & 5 & 5 & -64.72 & 2 & 8 & 19.83 & 4 & 6 \\
\hline $1971-80$ & 2.35 & 6 & 4 & -17.53 & 3 & 7 & 11.22 & 6 & 4 \\
\hline $1981-90$ & -33.11 & 1 & 9 & 38.81 & 4 & 6 & -47.53 & 0 & 10 \\
\hline $1991-2000$ & -16.55 & 2 & 8 & 14.78 & 4 & 6 & -46.10 & 1 & 9 \\
\hline $2001-15$ & 10.35 & 9 & 6 & -53.56 & 3 & 12 & -13.81 & 2 & 13 \\
\hline Rainfall (mm) & 1628.64 & & & 51.93 & & & 1692.3 & & \\
\hline Linear equation & $y=-0.696 x+1669$ & & & $y=-0.169 x+61.76$ & & & $y=-6.375 x+1916$ & & \\
\hline \multicolumn{10}{|c|}{ Bharuch } \\
\hline $1901-10$ & -7.83 & 5 & 5 & -81.81 & 1 & 9 & -10.87 & 5 & 5 \\
\hline $1911-20$ & -5.44 & 5 & 5 & 101.19 & 4 & 6 & 0.80 & 5 & 5 \\
\hline $1921-30$ & 0.26 & 6 & 4 & -22.86 & 3 & 7 & -1.43 & 5 & 5 \\
\hline $1931-40$ & -0.13 & 6 & 4 & 89.90 & 6 & 4 & 2.49 & 6 & 4 \\
\hline $1941-50$ & 17.15 & 8 & 2 & 10.23 & 3 & 7 & 17.64 & 6 & 4 \\
\hline $1951-60$ & 12.44 & 6 & 4 & 69.77 & 4 & 6 & 14.19 & 6 & 4 \\
\hline $1961-70$ & 1.01 & 4 & 6 & -61.40 & 1 & 9 & -2.41 & 3 & 7 \\
\hline $1971-80$ & -5.09 & 5 & 5 & -7.24 & 4 & 6 & -5.91 & 4 & 6 \\
\hline $1981-90$ & -2.59 & 4 & 6 & 22.63 & 4 & 6 & -11.65 & 3 & 7 \\
\hline $1991-2000$ & -9.50 & 4 & 6 & -25.77 & 3 & 7 & -50.31 & 0 & 10 \\
\hline $2001-15$ & -0.18 & 8 & 7 & 14.91 & 2 & 13 & -36.05 & 2 & 13 \\
\hline Rainfall (mm) & 776.29 & & & 32.33 & & & 822.53 & & \\
\hline Linear equation & $y=-0.009 x+776.8$ & & & $y=-0.014 x+36.48$ & & & $y=-2.971 x+922.2$ & & \\
\hline
\end{tabular}




\section{Int.J.Curr.Microbiol.App.Sci (2017) 6(10): 4805-4815}

Table.2 Decadal mean (\% departure from normal) of excess, deficit rainfall and linear equation and over Surat and Valsad from 1901 to 2015

\begin{tabular}{|c|c|c|c|c|c|c|c|c|c|}
\hline \multirow[b]{2}{*}{ Decades } & \multicolumn{3}{|l|}{ Monsoon } & \multicolumn{3}{|c|}{ Post-monsoon } & \multicolumn{3}{|c|}{ Annual } \\
\hline & $\begin{array}{c}\text { Decadal mean } \\
\text { (\% departure from normal) }\end{array}$ & Excess & Deficit & $\begin{array}{c}\text { Decadal mean } \\
\text { (\% departure from } \\
\text { normal) }\end{array}$ & Excess & Deficit & $\begin{array}{c}\text { Decadal mean } \\
\text { (\% departure from } \\
\text { normal })\end{array}$ & Excess & Deficit \\
\hline \multicolumn{10}{|c|}{ Surat } \\
\hline 1901-10 & -17.28 & 3 & 7 & -71.90 & 0 & 10 & -18.44 & 3 & 7 \\
\hline $1911-20$ & -14.19 & 3 & 7 & 86.76 & 5 & 5 & -10.46 & 5 & 5 \\
\hline $1921-30$ & -5.85 & 4 & 6 & -34.57 & 1 & 9 & -6.66 & 4 & 6 \\
\hline $1931-40$ & -5.10 & 4 & 6 & 95.52 & 6 & 4 & -1.62 & 5 & 5 \\
\hline $1941-50$ & 3.85 & 4 & 6 & 2.04 & 4 & 6 & 3.88 & 4 & 6 \\
\hline $1951-60$ & 4.67 & 5 & 5 & 61.50 & 4 & 6 & 6.38 & 5 & 5 \\
\hline $1961-70$ & 5.80 & 5 & 5 & -69.53 & 1 & 9 & 3.43 & 5 & 5 \\
\hline $1971-80$ & 6.79 & 5 & 5 & 2.04 & 5 & 5 & 6.50 & 5 & 5 \\
\hline $1981-90$ & -4.10 & 3 & 7 & 19.41 & 4 & 6 & -3.56 & 3 & 7 \\
\hline $1991-2000$ & -0.88 & 4 & 6 & -22.71 & 4 & 6 & -1.89 & 4 & 6 \\
\hline 2001-15 & 17.53 & 10 & 5 & -45.71 & 2 & 13 & 14.95 & 8 & 7 \\
\hline Rainfall (mm) & 1186.91 & & & 40.53 & & & 1233.18 & & \\
\hline Linear equation & $y=2.871 x+1020$ & & & $y=-0.153 x+49.46$ & & & $y=2.617 x+1081$ & & \\
\hline \multicolumn{10}{|c|}{ Valsad } \\
\hline $1901-10$ & -23.29 & 0 & 10 & -83.62 & 0 & 10 & -24.45 & 0 & 10 \\
\hline $1911-20$ & -19.96 & 4 & 6 & 67.84 & 6 & 4 & -16.48 & 3 & 7 \\
\hline $1921-30$ & -13.40 & 2 & 8 & -70.05 & 1 & 9 & -14.78 & 2 & 8 \\
\hline $1931-40$ & -5.48 & 6 & 4 & 9.77 & 2 & 8 & -3.05 & 7 & 3 \\
\hline $1941-50$ & 2.78 & 6 & 4 & 38.21 & 5 & 5 & 2.71 & 6 & 4 \\
\hline $1951-60$ & 5.42 & 5 & 5 & 28.05 & 4 & 6 & 6.31 & 6 & 4 \\
\hline $1961-70$ & 2.42 & 4 & 6 & -67.14 & 1 & 9 & -0.08 & 4 & 6 \\
\hline $1971-80$ & 1.70 & 5 & 5 & -30.90 & 3 & 7 & 0.39 & 5 & 5 \\
\hline $1981-90$ & -0.58 & 4 & 6 & -10.93 & 5 & 5 & 0.35 & 3 & 7 \\
\hline $1991-2000$ & 11.91 & 6 & 4 & 181.55 & 4 & 6 & 8.19 & 6 & 4 \\
\hline $2001-15$ & 25.65 & 10 & 5 & -41.85 & 2 & 13 & 23.36 & 11 & 4 \\
\hline Rainfall (mm) & 1833.16 & & & 60.44 & & & 1902.80 & & \\
\hline Linear equation & $y=7.149 x+1418$ & & & $y=0.309 x+42.49$ & & & $y=6.794 x+1499$ & & \\
\hline
\end{tabular}




\section{Int.J.Curr.Microbiol.App.Sci (2017) 6(10): 4805-4815}

Table.3 Decadal mean (\% departure from normal) of excess, deficit rainfall and linear equation and over Dang from 1901 to 2015

\begin{tabular}{|c|c|c|c|c|c|c|c|c|c|}
\hline \multirow[b]{2}{*}{ Decades } & \multicolumn{3}{|l|}{ Monsoon } & \multicolumn{3}{|c|}{ Post-monsoon } & \multicolumn{3}{|c|}{ Annual } \\
\hline & $\begin{array}{c}\text { Decadal mean } \\
\text { (\% departure from normal) }\end{array}$ & Excess & Deficit & $\begin{array}{c}\text { Decadal mean } \\
\text { (\% departure from } \\
\text { normal) }\end{array}$ & Excess & Deficit & $\begin{array}{c}\text { Decadal mean } \\
\text { (\% departure from } \\
\text { normal) }\end{array}$ & Excess & Deficit \\
\hline & & & & Dang & & & & & \\
\hline $1901-10$ & -25.09 & 0 & 8 & 0.00 & 1 & 7 & -26.15 & 0 & 8 \\
\hline $1911-20$ & -13.69 & 4 & 6 & 18.01 & 3 & 7 & -12.26 & 4 & 6 \\
\hline $1921-30$ & -16.27 & 1 & 9 & -43.40 & 1 & 9 & -17.16 & 1 & 9 \\
\hline $1931-40$ & 0.33 & 5 & 5 & 55.40 & 7 & 3 & 2.74 & 5 & 5 \\
\hline $1941-50$ & 15.35 & 6 & 4 & -17.29 & 4 & 6 & 14.28 & 7 & 3 \\
\hline $1951-60$ & -1.01 & 6 & 4 & 38.99 & 5 & 5 & 0.79 & 6 & 4 \\
\hline $1961-70$ & -3.40 & 3 & 7 & -36.76 & 3 & 7 & -4.14 & 5 & 5 \\
\hline $1971-80$ & -6.70 & 4 & 6 & -31.41 & 2 & 8 & -7.65 & 4 & 6 \\
\hline $1981-90$ & -3.52 & 4 & 6 & -26.95 & 2 & 8 & -4.69 & 4 & 6 \\
\hline 1991-2000 & 21.25 & 7 & 3 & 91.79 & 7 & 3 & 23.38 & 5 & 5 \\
\hline $2001-15$ & 18.48 & 11 & 4 & -1.52 & 4 & 11 & 17.09 & 8 & 7 \\
\hline Rainfall (mm) & 1857.01 & & & 73.39 & & & 1941.38 & & \\
\hline Linear equation & $y=5.994 x+1503$ & & & $y=0.216 x+60.63$ & & & $y=6.08 x+1582$ & & \\
\hline
\end{tabular}


Fig.1-2 Location map

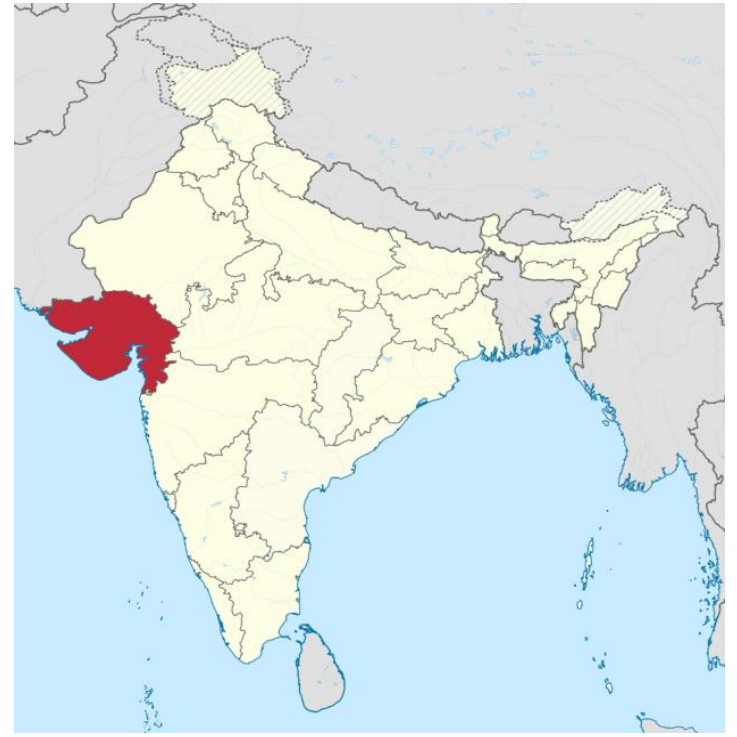

Valsad District

\section{Annual}

The investigation of annual rainfall make known that at Valsad district, the 53 excess and 62 deficit years were observed. During decade 2001-15, 1991-2000 and 1951-60 highest rainfall were documented including percent increase 23.36, 8.19 and 6.31 respectively. Likewise, meanwhile decades 1901-10, 1911-20 and 1921-30 lowest rainfall were confirmed with percent decrease -24.45 , -16.48 and -14.78 respectively (Table 2 ).

The scrutiny of annual rainfall discloses that at Valsad district, during decades 2001-15, 1931-40 and 1941-50 excess events of rainfall were scrutinized with no. 11,7 and 6 respectively. In the same way, thought decades 1901-10, 1921-30 and 1911-20 deficit rainfall incidents were noticed with no. 10, 8 and 7 respectively (Table 2).

\section{Monsoon}

The study of monsoon rainfall reveals that at Valsad district, the 52 excess and 63 deficit

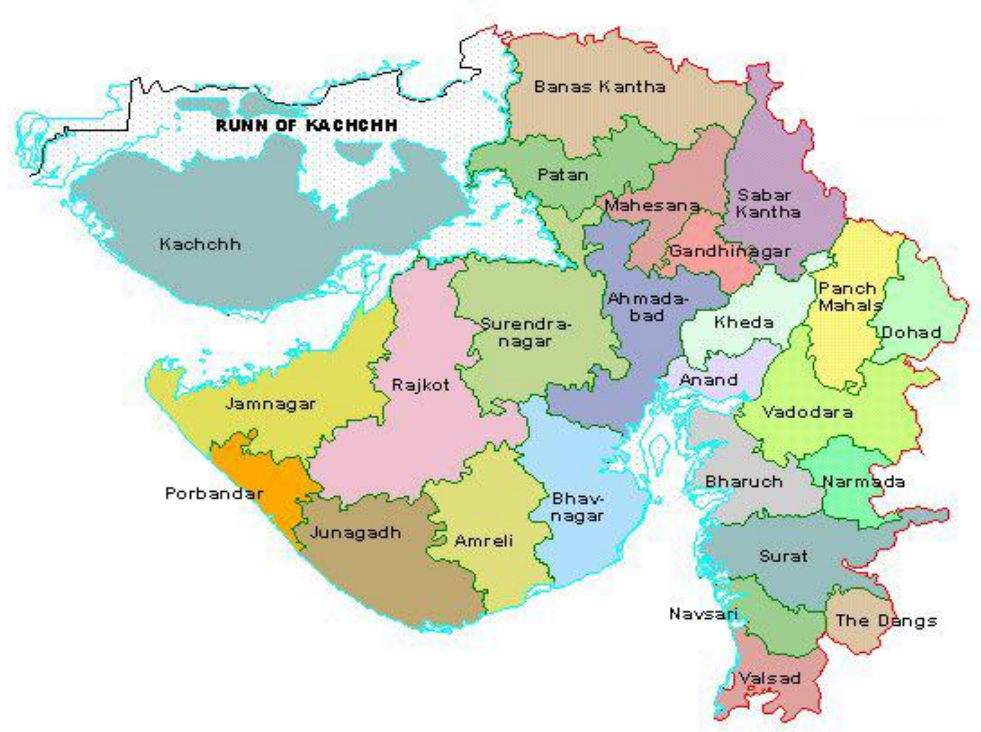

years were reported. During decades 2001-15, 1991-2000 and 1951-60 highest rainfall were recorded along with percent increase 25.65, 11.91 and 5.42 respectively. Equally, along decades 1901-10, 1911-20 and 1921-30 lowest rainfall were confirmed with percent decrease $-23.29,-19.96$ and -13.40 respectively (Table 2).

The investigation of monsoon rainfall reveals that at Valsad district, all the while decades 2001-15, 1991-2000 and 1941-50 highest excess events of rainfall were observed with no. 10, 6 and 6 respectively. Similarly, in the course of decades 1901-10, 1921-30 and 1911-20 deficit rainfall cases were divulged with no. 10, 8 and 6 respectively (Table 2).

\section{Post monsoon}

The scrutiny of post monsoon rainfall reveals that at Valsad district, the 33 excess and 82 deficit years were noticed. During decades 1991-2000, 1911-20 and 1941-50 highest rainfall were recorded alongside percent increase 181.55, 67.84 and 38.21 respectively. Correspondingly, in the interim of decades 1901-10, 1921-30 and 1961-70 lowest rainfall 
were perceived with percent decrease -83.62 , -70.05 and -67.14 respectively (Table 2 ).

The analysis of post monsoon rainfall affirmed that at Valsad district, in the meanwhile decades 1911-20, 1941-50 and 1981-90 highest excess incidents of rainfall were observed with no. 6,5 and 5 respectively. Also, meanwhile decades 2001$15,1901-10$ and 1921-30 deficit rainfall events were distinguished with no. 13, 10 and 9 respectively (Table 2 ).

\section{Dang district}

\section{Annual}

The analysis of annual rainfall acknowledges that at Dang district, the 49 excess and 64 deficit years were observed. Through decades 1991-2000, 2001-15 and 1941-50 highest rainfall were recorded amidst percent increase 23.38, 17.09 and 14.28 respectively. Similarly, during decades 1901-10, 1921-30 and 1911-20 lowest rainfall were evidenced with percent decrease $-26.15,-17.16$ and 12.26 respectively (Table 3 ).

The study of annual rainfall affirms that at Dang district, all along decades 2001-15, 1941-50 and 1951-60 excess incidents of rainfall were noticed with no. 8,7 and 6 respectively. Alike, all the while decades 1921-30, 1901-10 and 2001-15 deficit rainfall events were documented with no. 9,8 and 7 respectively (Table 3 ).

\section{Monsoon}

The investigation of monsoon rainfall concedes that at Dang district, the 51 excess and 62deficit years were discerned. During decades 1991-2000, 2001-15 and 1941-50 highest rainfall were recorded including percent increase 21.25, 18.48 and 15.35 respectively. Correspondingly, in the course of decades 1901-10, 1921-30 and 1911-20 lowest rainfall were noticed with percent decrease $-25.09, \quad-16.27$ and -13.69 respectively (Table 3 ).

The study of monsoon rainfall divulges that at Dang district, in the mean while decades 2001-15, 1991-2000 and 1941-50 highest excess events of rainfall were observed with no. 11,7 and 6 respectively. Equivalently, during decades 1921-30, 1901-10 and 196170 deficit rainfall incidents were perceived with no. 9, 8 and 7 respectively.

\section{Post monsoon}

The examination of post monsoon rainfall explains that at Dang district, the 39 excess and 74 deficit years were detected. Meanwhile decades 1991-2000, 1931-40 and 1951-60 highest rainfall were recorded with percent increase $91.79,55.40$ and 38.99 respectively. Furthermore, during decades 1921-30, 1961-70 and 1971-80 lowest rainfall were distinguished with percent decrease 43.40, -36.76 and -31.41 respectively (Table $3)$.

The scrutiny of post monsoon rainfall imparts that at Dang district, during decades 1931-40, 1991-2000 and 1951-60 highest excess incidents of rainfall were discerned with no. 7, 7 and 5 respectively. In addition, meanwhile decades 2001-15, 1921-30 and 1971-80 deficit rainfall cases were spotted with no. 11, 9 and 8 respectively (Table 3 ).

Precipitation trend analysis, on different scales, has been of great concern during the past century because of the attention given to global climate change by the scientific community. Studies of changes in climate extremes have become more prevalent since the Assessment of the Intergovernmental Panel on Climate Change determined that analyses of extremes were inadequate. Since 
then, studies of regional and global-scale changes in extremes have attempted to answer the question of whether or not the climate is becoming more extreme and variable. An important culmination of the present study is the increase in southwest monsoon rainfall while decline in post monsoon rainfall for all the districts of south Gujarat. Decadal analysis on Navsari district reveals that during decades 1901-10, 1951-60, 1961-70, 1971-80 and 2001-15 increasing trends were observed. Bharuch district investigation acknowledges that during decades 1901-10, 1921-30, 195160, 1961-70, 1991-2000 and 2001-15 increasing trends were observed. The more number of excess rainfall years were found in Dang, Valsad and Surat as compared to Navsari and Bharuch districts. Similarly the more number of deficit rainfall years were found in Navsari and Bharuch as evaluated to Dang, Valsad and Surat districts.

\section{Acknowledgement}

The authors are thankful to India Meteorological Department, Pune for facilitating this work. Authors are also grateful to anonymous reviewer for his valuable comments to improve the quality of research paper.

\section{References}

CIA, 2012. The World fact book, https://www.cia.gov/library/publications /the-world-factbook/geos/in.html Accessed 6 January 2014.

Gadgil, S., and Gadgil S., 2006. The Indian monsoon GDP and agriculture. Econ Polit wkly, 41 (47) 4887-4895.

Kumar, K. K., Rajagopalan B., Hoerling, M., Bates G. and Cane M., 2006. Unraveling the mystery of Indian Monsoon failure during El Niño. Science, 314, 115-119.

Kumar, N., and Patel J. G., 2012. Analysis of regional drought intensity and frequency over north Gujarat. Journal of Agrometeorology, 14 (1): 95-96.

Kumar, N., Pisal, R. R., Shukla S. P. and Patel, S. S., 2015. Analysis of climatic variability at heavy rainfall zone of South Gujarat. Mausam, 66 (4): 850856.

Pant, G.B., and Rupa Kumar K., 1997. Climate of South Asia. John Wiley and sons, Chichester, 320.

Ranade, A., Singh N, Singh, H. N. and Sontakke N. A., 2008. On variability of hydrological wet season, seasonal rainfall and rainwater potential of the river basins of India (1813-2006). J Hydrol Res Dev, 23: 79-108.

Ray, K., Mohanty, M. N. A. and Chincholikar J. R, 2009. Climate variability over Gujarat, India. ISPRS Archivers XXXVIII-8/W3 Workshop Proceedings, Impact of Climate change on Agriculture.

Sahu, D. D., 2007. Text book of Agrometeorology and remote sensing principles and practices. 43-44.

Turner, A.G., and Annamalai, H., 2012. Climate change and the South Asian summer monsoon. Nature Climate Change, 10:1495.

\section{How to cite this article:}

Neeraj Kumar, S.K. Chandrawanshi, N.V. Chaudhari, Ashok Patidar, S.N. Chaudhari and Radadia, G.G. 2017. Decadal Trend Analysis of Annual and Seasonal Rainfall of Past 115 Years at South Gujarat. Int.J.Curr.Microbiol.App.Sci. 6(10): 4805-4815. doi: https://doi.org/10.20546/ijcmas.2017.610.448 